\title{
Policy Supports for Financial Stability
}

\author{
Dr. Kameswari Peddada
}

Professor, Faculty of Business Studies, Arab Open University Kuwait, Al-Ardia, State of Kuwait

DOI: $10.36348 /$ sjef.2020.v04i07.003

| Received: 02.07.2020 | Accepted: 09.07.2020 | Published: 12.07.2020

*Corresponding author: Dr. Kameswari Peddada

\section{Abstract}

The global financial crisis of 2008 has exposed numerous shortcomings in the traditional safeguards for financial stability in terms of different economic policies adopted so far. A system level perspective focusing on systemic risks with suitable policies and instruments was the felt need to combat vulnerabilities at their origin before spreading. The present study has analyzed the various policy options, indicators of systemic vulnerabilities, choice of tools and instruments for the regulatory and supervisory bodies for a granular approach in different settings. Macroprudential policy and its tools were found to be a suitable solution, either alone or in conjunction with other economic policies.

Keywords: Financial Stability, Financial Crisis, Economic Policies, Financial Regulation \& Supervision, Macroprudential Policy, Granular Approach.

JEL Classification: E44, E52, E58, F42, F43, F44, F45, G12, G21, G28.

Copyright @ 2020: This is an open-access article distributed under the terms of the Creative Commons Attribution license which permits unrestricted use, distribution, and reproduction in any medium for non-commercial use (NonCommercial, or CC-BY-NC) provided the original author and source are credited.

\section{INTRODUCTION}

The world financial crisis (WFC) of 2008 exposed huge chinks in the armor of world's financial stability [1, 2]. The root causes were lax financial regulation, shallow and greedy search for yield by institutions and investors, close integration of world trade increasing risks of cross-contagion, flawed notion on self-regulation of markets, more dependence of banks on wholesale sources of funds rather than on traditional customer deposits, and financial innovations passing on toxic loans as securities to investors. Traditional policies to safeguard soundness of individual financial institutions, as well as monetary and fiscal policies were found inadequate to stabilize the financial system. There was a felt-need for a system level perspective with focus on systemic risks and suitably designed policies and instruments to combat vulnerabilities in the economy at their origin before spreading widely.

\section{REVIEW OF LITERATURE Financial Stability}

Definition: Financial stability is a state of financial system remaining resistant to economic shocks and smoothly fulfilling its basic functions of intermediation of financial funds, management of risks and arrangement of payments [3]. The three components of financial system are financial institutions, financial markets and financial infrastructure. Financial institutions consist of banking system and non-banking institutions, such as brokerage firms, investment funds, insurers and other funds. Stable financial institutions perform their financial intermediation adequately with no external assistance, as from the government. Stable financial markets enable market transactions without major disruptions or significant asset price fluctuations, thereby enabling economic agents to raise and operate funds with confidence. Stable financial infrastructure ensures a smooth operation of a well-structured financial system under market discipline and an effectively running financial safety net and payment and settlement system [4]. The common denominator for stability is a stressresistant and fail-proof financial system [5].

Financial Instability: The causes are rapid liberalization, inadequate economic policy, non-credible exchange rate mechanism, inefficient resource allocation, weak supervision, poor accounting and audit regulation, and scant market discipline, emerging individually, randomly or collectively [3]. It imposes heavy economic costs by impeding healthy development of economy [5]. Rational decisions and efficient allocation of resource are affected with banks reluctant to finance profitable projects, wide fluctuation of asset prices off their intrinsic value, and delayed payments. People may lose confidence in the financial and economic system resulting in bank runs, hyperinflation, stock market crash and financial crisis. 
Financial institutions, corporations and even governments go bankrupt.

Financial Crises: Some may be too mild to have an impact outside the financial sector, while others may affect national economy, other countries, regions and the world [2]. The three associated terms are: recession [a negative growth of gross domestic product (GDP) over two or more quarters], depression (a severe and prolonged recession), and stagnation (a long period of slow, but not necessarily negative, GDP growth).

Importance of Financial Stability: With the emergence of increased global financial interconnectedness and development of complex financial instruments governments are paying more attention to financial stability in implementing their economic policies [4]. A stable system enables efficient allocation of resources, management of financial risks, maintaining employment levels close to the economy's natural rate, eliminating relative price movements of real or financial assets, and dissipating exogenous and endogenous imbalances by self-correcting mechanisms, thereby preventing disruption of real economy. Financial stability is essential, not only for price stability, but for economic growth [5]. A stable system provides crucial services for households and businesses in good times and bad, like enabling payments for buying or selling of goods and services, managing and insuring against risks, managing savings, and borrowing of money for investment and growth [6].

Measurement of Financial Stability: Stability analysis can be simplified by focusing on monitoring and assessment of risks with high probability of occurrence [7]. A framework (Fig-1) is required for supervision, regulation and surveillance by information gathering on the macro-economy and financial system to assess risks and suggest suitable actions.

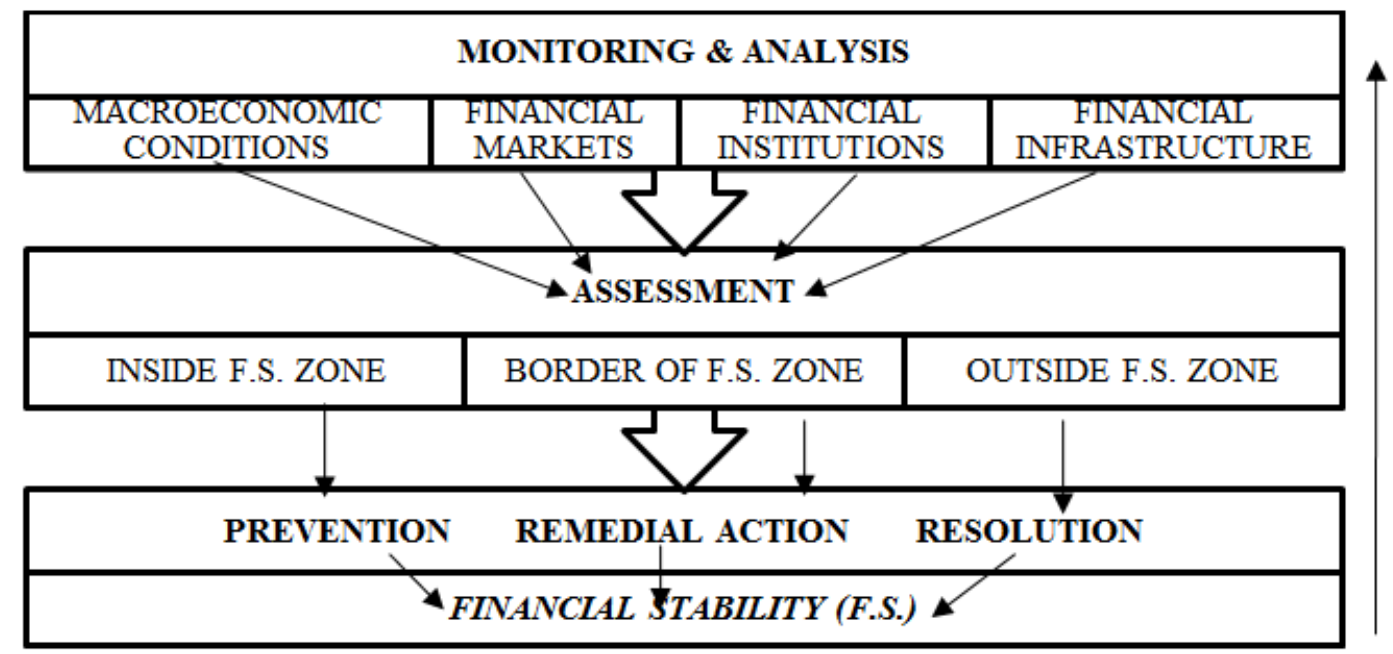

Fig-1: Framework for Maintaining Financial System Stability

Source: Adapted from ECB, p.124. [7]

Analysis and measurement of overall stability [5] is an extremely complex task, as focus on individual institutions distorts overall picture.

Firm-level stability measures: a.) Altman's Zscore compares buffers (capitalization \& returns) with risks (volatility of returns) to measure a bank's solvency risk; widely used in empirical research. b.) Merton or Asset Value Model ascertains a firm's ability to meet financial obligations to gauge overall possibility of default. c.) Distance to Default (D-D) is a market-based corporate default measure (Merton's model) of solvency and liquidity risks.

Systemic Stability Measures (no single standardized model): a.) Aggregation of Firm-level Stability Measures (z-score/D-D) ignores the interconnectedness of financial institutions. b.) First-todefault Probability (for large financial institutions) uses risk-neutral default probabilities from credit default swap spreads. Despite considering connectivity of defaults among institutions, it overlooks difference in magnitude of impact between large and small institutions. c.) Systemic Expected Shortfall (SES) measures each institution's contribution to systemic risk, considering its leverage and risk-taking and measures externalities from banking sector's failure to the real economy; being retrospective, prediction of likely time of failure is difficult. d.) SRISK, an empirical methodology to measure contribution of financial firms to 'systemic risk' (S-RISK) and an extension of retrospective SES to be more predictive; considers firm's size, degree of leverage, and expected equity loss from market decline, i.e. long run marginal expected shortfall (LRMES); sum of SRISK of all firms is a measure of overall systemic risk. e.) Distribution of Systemic Loss combines probability and size of loss and contagious nature of default of an institution. f.) Financial Soundness Indicators consider ratio of regulatory capital to risk-weighted assets and ratio of 
nonperforming loans to total gross loans to assess credit growth easily. But assessment of growth beforehand as excessive is difficult. A resilience indicator devised by Rojas Suarez in 2015 [8] to gauge susceptibility of an economy to external shocks is a relative measure to indicate the rank of an economy in question in comparison to a group of other country economies included in a sample. It is an aggregate of seven standardized variables. Lesser the value, stronger is the resilience. g.) Proxy Variables of Market Stability include market volatility, skewness of stock returns, vulnerability to earnings manipulation and price-toearnings ratio \& duration.

Contributors to Financial Stability [6]: a.) Prudential regulation: Tough regulations for high resilience of institutions encourage honest behavior and limit excess risk taking with other's money. b.) Annual stress testing: It ensures institutional adequacy and adaptability in financial resources to provide financial services in bad times and good. c.) Financial policy tools: They enable institutions to absorb shocks and prevent worsening of risk.

\section{Economic Policies for Financial Stability}

Macroprudential Policy (MaPP): It preserves stability of the whole financial system with "prudential" supervision and regulatory instruments [9]. WFC has revealed gaps in institutional frameworks, and inadequacies in the financial sector supervision, such as lack of appropriate mandates, and analytical tools and instruments to deal with systemic risks. It showed that price stability without financial stability does not guarantee macroeconomic stability. The need for suitable supervision to identify risks early and become resistant to internal and external shocks was recognized. MaPP ensures detailed analysis of risks through identification and assessment of their severity through indicators (Table-1), assesses the stability of financial system, communicates warnings against risks, and identifies preventive actions. As the first line of defense against financial instability, it contributes to a sustainable economic growth, either alone, or in coordination with other policies.

Table-1: Summary of Macroprudential Indicators

\begin{tabular}{|c|c|}
\hline Aggregated Microprudential Indicators & Macroeconomic Indicators \\
\hline $\begin{array}{l}\text { Capital adequacy } \\
\text { Adequate capital ratios } \\
\text { Frequency distribution of capital ratios }\end{array}$ & $\begin{array}{l}\text { Economic growth } \\
\text { Adequate growth rates } \\
\text { Sectoral slumps }\end{array}$ \\
\hline $\begin{array}{l}\text { Asset quality: Lending Institution } \\
\text { Sectoral credit concentration } \\
\text { Foreign currency-denominated lending } \\
\text { Nonperforming loans and provisions } \\
\text { Loans to loss-making public sector entities } \\
\text { Risk profile of assets } \\
\text { Connected lending \& Leverage ratios } \\
\text { Borrowing entity } \\
\text { Debt-equity ratios \& Corporate profitability } \\
\text { Other indicators of corporate conditions } \\
\text { Household indebtedness }\end{array}$ & $\begin{array}{l}\text { Balance of payments } \\
\text { Current account deficit } \\
\text { Foreign exchange reserve adequacy } \\
\text { External debt (incl. maturity structure) } \\
\text { Terms of trade } \\
\text { Composition \& maturity of capital flows }\end{array}$ \\
\hline $\begin{array}{l}\text { Management soundness } \\
\text { Expense ratios \& Earnings per employee } \\
\text { Growth in the number of financial institutions }\end{array}$ & $\begin{array}{l}\text { Inflation } \\
\text { Volatility in inflation }\end{array}$ \\
\hline $\begin{array}{l}\text { Earnings and profitability } \\
\text { Return on assets } \\
\text { Return on equity } \\
\text { Income and expense ratios } \\
\text { Structural profitability indicators }\end{array}$ & $\begin{array}{l}\text { Interest and exchange rates } \\
\text { Volatility in interest and exchange rates } \\
\text { Level of domestic real interest rates } \\
\text { Exchange rate sustainability } \\
\text { Exchange rate guarantees }\end{array}$ \\
\hline $\begin{array}{l}\text { Liquidity } \\
\text { Central bank credit to financial institutions } \\
\text { Segmentation of interbank rates } \\
\text { Deposits in relation to monetary aggregates } \\
\text { Loans-to-deposits ratios } \\
\text { Maturity structure of assets/liabilities } \\
\text { Measures of secondary market liquidity }\end{array}$ & $\begin{array}{l}\text { Lending and asset price booms } \\
\text { Lending booms } \\
\text { Asset price booms }\end{array}$ \\
\hline $\begin{array}{l}\text { Sensitivity to market risk } \\
\text { Foreign exchange risk \& Interest rate risk } \\
\text { Equity price risk \& Commodity price risk }\end{array}$ & $\begin{array}{l}\text { Contagion effects } \\
\text { Trade spillovers } \\
\text { Financial market correlation }\end{array}$ \\
\hline $\begin{array}{l}\text { Market-based indicators } \\
\text { Market prices of financial instruments incl. equity, Indicators of excess yields } \\
\text { Credit ratings \& Sovereign yield spreads }\end{array}$ & $\begin{array}{l}\text { Other factors } \\
\text { Direct lending and investment } \\
\text { Government recourse to banking system } \\
\text { Arrears in the economy }\end{array}$ \\
\hline
\end{tabular}

Source: International Monetary Fund [10] 
Though its primary concern is banking sector stability, inclusion of non-banking institutions would strengthen supervision and transparency. It is nondiscretionary, and responds harmoniously against situations, like booms and busts of the economy. International coordination is important in cross-border issues, like insufficient national actions, differences in economic cycles of countries, and conflicts between home and host authorities of multinational financial institutions.
Clarity on objectives, proper assignment of mandates, timely and appropriate policy actions, safeguards against political pressure, and a legal foundation would ensure a strong institutional framework (Table-2). The two risks in implementation are 'inaction' from lack of clarity in mandates and political interference, and 'too much action' in use of MaPP alone, rather than in coordination with other economic policies.

Table-2: Principles for Strong Institutional Framework

\begin{tabular}{|c|l|l|}
\hline$\#$ & Principles & Supporting Elements \\
\hline 1. & $\begin{array}{l}\text { Willingness to act by timely and proper use of } \\
\text { MaPP tools }\end{array}$ & $\begin{array}{l}\text { Well-designed objective \& accountability } \\
\text { Clear mandate \& power assignment } \\
\text { Strong role for the central bank }\end{array}$ \\
\hline 2. & $\begin{array}{l}\text { Ability to act by effective identification \& } \\
\text { monitoring of systemic risk }\end{array}$ & $\begin{array}{l}\text { Access to relevant information } \\
\text { Use of existing resources \& expertise } \\
\text { Power to initiate use of tools \& to calibrate tools } \\
\text { Mechanism to challenge dominant views }\end{array}$ \\
\hline 3. & $\begin{array}{l}\text { Accountability \& transparency in guiding exercise } \\
\text { of power }\end{array}$ & $\begin{array}{l}\text { Internal \& external checks \& balances } \\
\text { Periodic assessment of effectiveness \& cost }\end{array}$ \\
\hline 4. & $\begin{array}{l}\text { Effective coordination with policies that also affect } \\
\text { systemic risk }\end{array}$ & $\begin{array}{l}\text { Monetary/fiscal/micro-prudential policies } \\
\text { Key when power over tools is with other bodies } \\
\text { Autonomy of separate policies }\end{array}$ \\
\hline
\end{tabular}

Source: Vucinic [9]

Key aspects of the policy include: a.) Developing systemic risk assessment capacity, b.) Selection and assembly of toolkit, c.) Calibration of tools and communication with the public and the markets, d.) Monitoring \& closure of regulatory gaps, and e.) Identification \& closure of data gaps.

European Systemic Risk Board [11] has identified 5 intermediate objectives (Table-3), 4 for banking sector stability and 1 beyond the banking sector, to achieve the ultimate objective (Fig-2). Introduction of the capital requirement directive and capital requirement regulation (CRD \& CRR), a new global standard on bank capital termed the Basel III, by ESRB

in 2014 has set stronger prudential requirements for banks, like sufficient capital reserves and liquidity. Table-3:

Intermediate Objectives \& Instruments

\begin{tabular}{|c|c|c|}
\hline \# & INTERMEDIATE OBJECTIVE & INSTRUMENTS \\
\hline 1. & $\begin{array}{l}\text { Excessive credit growth and leverage: (unsustainable } \\
\text { developments in the real estate market leading to private sector } \\
\text { leverage) }\end{array}$ & $\begin{array}{l}\text { *Countercyclical Capital Buffer (CCB) } \\
\text { *Sectoral Capital Requirements } \\
\text { *Macroprudential Leverage Ratio } \\
\text { *Loan-To-Value (LTV) Ratio Requirements } \\
\text { *Loan-To-Income (LTI) Ratio Requirements }\end{array}$ \\
\hline 2. & $\begin{array}{l}\text { Excessive maturity mismatch and illiquidity: (short term \& } \\
\text { illiquid sources leading to fire sales, market illiquidity and } \\
\text { contagion) }\end{array}$ & $\begin{array}{l}\text { *Macroprudential Adjustment to Liquidity } \\
\text { Ratio/Liquidity Coverage Ratio (LCR) } \\
\text { *Macroprudential Restrictions on Funding } \\
\text { Sources/Net Stable Funding Ratio (NSFR) } \\
\text { *Macroprudential Unweighted Limit to Less } \\
\text { Stable Funding (Loan-to-Deposit Ratio) } \\
\text { *Margin and Haircut Requirements }\end{array}$ \\
\hline 3. & $\begin{array}{l}\text { Direct exposure (to specific sector/asset class) \& indirect } \\
\text { exposure (through asset fire sales and contagion) concentrations }\end{array}$ & $\begin{array}{l}\text { *Large Exposure Restrictions } \\
\text { *Central Counter Parties (CCP) Clearing } \\
\text { Requirement }\end{array}$ \\
\hline 4. & $\begin{array}{l}\text { Misaligned incentives to reduce moral hazard from "too-big-to- } \\
\text { fail" institutions }\end{array}$ & $\begin{array}{l}\text { *Systemically Important Financial Institutions } \\
\text { (SIFI) Capital Surcharges }\end{array}$ \\
\hline 5. & $\begin{array}{l}\text { Strengthening resilience of financial infrastructures not included } \\
\text { in the scope of banking sector }\end{array}$ & $\begin{array}{l}\text { *Margin \& Haircut Req. on CCP clearing } \\
\text { *Increased Disclosure } \\
\text { *Structural Systemic Risk Buffer }\end{array}$ \\
\hline
\end{tabular}

Source: ESRB Recommendation [11 


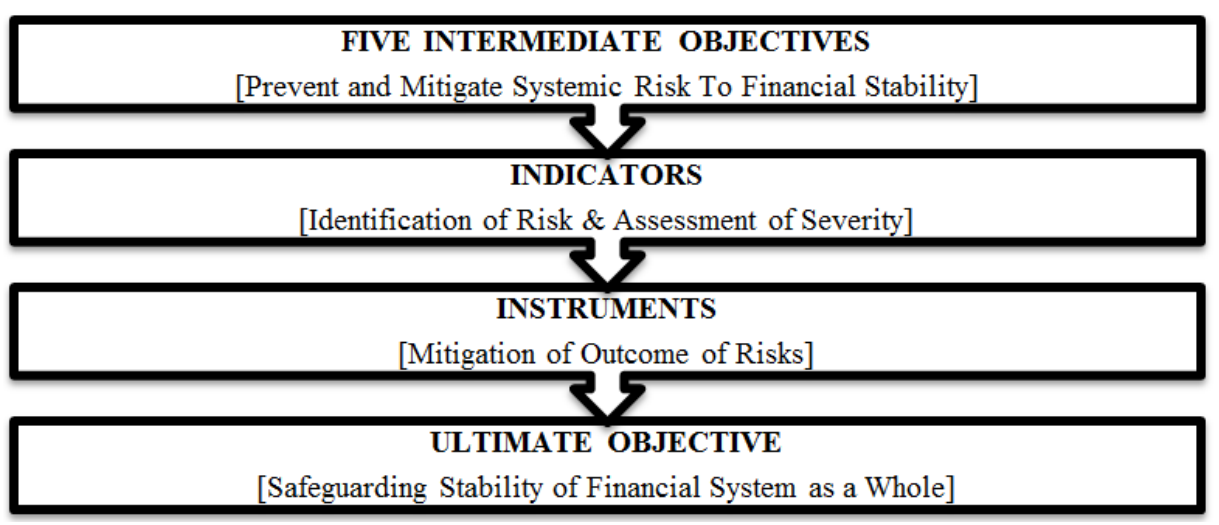

Fig-2: The Process: Intermediate to Ultimate Objective

Source: Adapted from ESRB Report on MaPP [12]

Responsibility for MaPP differs among countries. There are 3 identified models: a.) Full integration, where central bank is wholly responsible, b.) Partial integration with a specific committee for MaPP supervision within the central bank, and c.) Separate body for MaP supervision, like a committee outside the central bank. Each model having some pros and cons, the choice is based on legal framework, history, size of financial system, and others. The essential features include clear mandates, accountability, transparency, and a major role for and safeguards for independence of central bank.

Microprudential Policy (MiPP): It is an institution-level oversight to ensure robustness for consumer protection. It reduces systemic risk by preventing simultaneous failure of a large number of financial firms. Due to focus on individual institutions systemic implication of individual behavior in financial crisis is out of its purview [13]. A healthy financial system requires a balance between micro and macro prudential approaches [14]. Despite differences in scope, objectives, approach and type of risks covered several similarities and complementarities exist between them (Table-4).

Table-4: Comparison of Macro \& Micro Prudential Perspectives

\begin{tabular}{|l|l|l|}
\hline & Macro-prudential & Micro-prudential \\
\hline Proximate Objective & Limit financial system-wide distress & Limit distress of individual institutions \\
\hline Ultimate Objective & Avoid output (GDP) losses & Consumer protection \\
\hline Model of risk & Endogenous (Partly) & Exogenous \\
\hline $\begin{array}{l}\text { Correlations \& common exposures } \\
\text { across institutions }\end{array}$ & Important & Irrelevant \\
\hline Calibration of prudential controls & $\begin{array}{l}\text { In terms of system-wide distress; top- } \\
\text { down }\end{array}$ & $\begin{array}{l}\text { In terms of individual institutions; } \\
\text { bottom-up. }\end{array}$ \\
\hline
\end{tabular}
Source: Borio [15]

Relationship between MaPP and other Economic Policies [9]:

Monetary Policy: The main focus is price stability. Changes in monetary stance affect the financial sector, monetary easing leading to increase in asset prices, excessive leverage and price booms, and monetary tightening leading to collateral constraints and adverse asset price externalities. In productivity shock, if borrower's collateral is the problem, monetary policy easing is enough. In cases of financial shock, especially endogenous, monetary policy alone fails to solve it.

Fiscal and Structural Policies: They can minimize macroeconomic imbalances affecting financial stability. Prudent fiscal and structural policies alone would resolve the issue in consumption booms following a high current account deficit and not MaPP measures. Economic recovery would be facilitated by fiscal policy stimulus of lower taxation and better public investments, while structural policies can support the situation by creating better business conditions and public infrastructure. A strong fiscal policy is necessary to provide safety for sovereign debt, while avoiding adverse feedback loops between sovereign debt and financial system. Tax policies can create prejudice contributing to systemic risks, while MaPP measures would try to correct them.

Competition Policies: A prudential coordination of traditional competition policy measures, like assigning license, take-over control, and break-up powers, enables control of systemic risk. When financial institutions get too big by merger or take-over, 
they may endanger financial stability by their problems or bankruptcy.

Crisis Management \& Resolution Policies:
Crisis management includes monetary easing, emergency liquidity assistance by central bank for failing banks, public guarantees and capital support by fiscal authorities, which are complementary to MaPP. While MaPP authorities provide advice, suggestions, assessment of systemic risk levels and instruments, fiscal authorities coordinate policy response when using taxpayers' money. Creating proper resolution plans and regimes would strengthen market discipline and reduce the need for MaPP intervention.

Coordination among economic policies leads to synergies that contribute to an efficient and effective achievement of their objectives.

\section{Shadow Banking}

The system of credit intermediation involving entities and activities outside regular banking system is called shadow banking [9]. Its significance was realized following the WFC. Though it performs bank-like activities and plays an important role in the financial system by creating additional sources of funding and offering investors alternatives to bank deposits, it is not regulated like banks and can pose potential threats to long-term financial stability, unless better monitored and regulated ensuring transparent transactions.

\section{Economic Cycle}

Economic cycle (also called business or trade cycle) refers to overall state of economy going through a cyclical pattern, fluctuating between expansion/growth/boom and contraction/recession/bust [16]. GDP, interest rates, employment, and consumer spending are the factors that determine the current status of the economic cycle. The fluctuations are neither uniform nor predictable. The four stages are expansion, peak, contraction, and trough. There would be rapid growth, low interest rates, increasing production and build-up of inflationary pressures in expansion. The peak with maximum growth rate creates imbalances. Corrections occur with slowing of growth, fall in employment and stagnating prices in contraction. Economy hits a low point and growth begins to recover at trough. Governments and major financial institutions use fiscal and monetary policies to manage the course and effects of economic cycles. Businesses and investors benefit from the relevant knowledge.

\section{Prudential Approaches for Regulation and Supervision}

MaPP and MiPP are both important despite different approaches [17]. While MiPP covers likelihood of failure of individual financial institutions and associated risk-spillovers, MaPP seeks to minimize failure of a significant proportion of the financial system with their associated costs. Short run objectives of MiPP are inconsistent with long run objectives of MaPP leading to a short run tradeoff between them. The main elements of MiPP regulation are: 1. Risk-based supervision, 2. Deposit insurance, and 3. Financial consumer protection. A shift towards a more MaPPfocused policy regime is the current trend to achieve financial stability in view of market-wide risks, concerns over financial innovations and procyclicality of the financial system. Strengthening of MaPP aspect would achieve both MiPP and MaPP objectives by ensuring protection of consumers and depositors and at the same time achieving system-wide stability. The two main tasks in effective implementation of MaPP are:

1. Monitoring vulnerabilities from $\mathrm{MaP}$ indicators (Table-1) \& macro-stress tests.

2. Mitigation of identified risks: by reducing spillovers from failure of individually systemic institutions in cross-sectional instability and by use of important tools like dynamic capital buffers, higher quality capital, and contingent capital, and also others like loan to value ratios, liquidity risk management and levy on wholesale funding in time-related instability.

MaPP governance faces issues, like the need for adequate powers for supervisors to control systemic risks from an ever-innovative and evolving financial sector, and policy coordination between MaP authority and other stakeholders within and outside direct purview of the formal financial system, whose activities pose a systemic risk. The relationship between monetary and financial policy in particular plays a crucial role in the design of an effective MaPP.

MaPP and MiPP usually complement and reinforce each other. The health of individual institutions is necessary, and not a sufficient condition for system-wide stability. But a stable system contributes to the health of individual institutions. The complementarities and potential conflicts have to be identified to promote effective cooperation between them [18]. Conflicts occur from overlapping policy mandates and their application. Clarity on mandates, functions, and toolkits would maximize synergies and limit the negative consequences. Tensions, more likely at recession phase of the economic cycle and at crucial turning points, can be reduced by clear assignment of powers. Information sharing, joint analysis of risks, and general dialogue between the two authorities would reduce differences of opinion. Tensions would be unlikely, if policymakers encourage buildup of shockabsorbing buffers in good times, put effective resolution mechanisms in place to allow unviable institutions to exit safely, and ensure a credible joint communication strategy to bolster investor confidence in turbulent times. Solutions with flexibility for country-specific circumstances would improve coordination, like having a coordination committee, when policy mandates are held by different entities and clarity on which policy to prevail over the other, if held by a single authority. 
Some flexibility in policy design and arrangements is needed, as there is still uncertainty on impact of these policies and as understanding of systemic risk is evolving.

\section{Global Experiences in Restoring Financial Stability}

USA Experience: Affordable housing loan policies by the US Government since 1990's have been blamed for the origin of the WFC-2008 [2]. Other contributing factors included building up of the housing bubble, huge inflows of foreign funds, easy availability of credit, sub-prime mortgage and other predatory lending practices, diluted, inefficient, lax and outsourced financial supervision, numerous and complex financial innovations linked to toxic sub-prime mortgages, and unregulated growth of shadow banking. The immediate cause was bursting of the housing bubble with falling real estate prices. With rising rates of foreclosures, defaults and delinquencies of subprime and adjustable rate mortgages and increasing losses on other loan types the crisis expanded from the housing market to other sectors of economy leading to stock market crash, bankruptcy of several renowned financial institutions, sharp decline in citizens' wealth, loss of creditworthiness of consumers and businesses, tight credit conditions, decrease in real GDP, increasing unemployment and decline in innovation. US crisis spread to Europe and ultimately turned into the WFC.

In response the US Government enacted fiscal stimulus programs with different combinations of government spending and tax cuts. The Federal Reserve System (Federal Reserve or simply the Fed), the U.S. Central Bank, has initially employed "traditional" policy actions by reducing the federal funds rate from $5.25 \%$ in September 2007 to a range of $0-0.25 \%$ in December 2008, reflecting a marked downgrade in the economic outlook, increased downside risks to both output and inflation, and risk of deflation. Since December 2008 the Fed began to use its policy statements to provide forward guidance for the federal funds rate. The Fed also pursued two "nontraditional" policy actions: 1 . credit easing programs to facilitate credit flows and reduce the cost of credit, and 2. large scale asset purchase (LSAP) programs. With the federal funds rate near zero, the asset purchases were implemented to help push down longer-term public and private borrowing rates. With recovery still slow and grudging, the Fed's monetary policy strategy has continued to evolve in an attempt to stimulate economy and fulfill statutory mandate. By January 2010 markets have stabilized and most of the money spent on banks has been recovered. The recession that began in December 2007 has officially ended in June 2009 [19].

European Union (EU) Experience: The US crisis has spread into Europe [2] resulting in a number of European bank failures, declines in various stock indexes, and large reductions in the market value of equities and commodities. Exposure of corporate and institutional investors to 'toxic' US products and deleveraging of financial institutions accelerated the solvency crisis and caused a decrease in international trade. The crisis continued despite the coordinated efforts of political leaders, ministers of finance and directors of central banks to reduce fears. By October 2008 a currency crisis developed, with investors transferring vast capital resources into stronger currencies such as the yen, the US dollar and the Swiss Franc, leading many emerging European economies to seek aid from the International Monetary Fund.

European states before the WFC were responsible for their own MaP supervision. But after the crisis European Union was launched in 2014 with a single supervisory mechanism (SSM) and a single resolution mechanism (SRM) as its two pillars. The European Systemic Risk Board (ESRB) was established on 16 December 2010 in response to the ongoing financial crisis for the macro-prudential oversight of financial system. It is an independent body, hosted and supported by the European Central Bank (ECB). European Central Bank (ECB) was made responsible for MaPP information and intervention rights in relation to banks of the member states. Despite its powers it works in cooperation with the national supervisory authorities. It was entrusted with direct control over the financial institutions classified as significant for financial system stability.

Advanced EU economies tried stimulus packages, quantitative easing policies, and drastic cuts in lending rates to kick-start moribund economies [20]. Even unconventional monetary policies, like ultra low interest policy (ULIP) and negative interest rate policy (NIRP), were tried to stimulate liquidity in markets, investment in businesses, consumption, employment, and economic growth. They prevented a deep protracted slump, but did not deliver a strong, sustainable growth, nor banish deflation. They simply distorted the economy.

Financial stability review for EU [21] has complemented ECB's banking-centric prudential competencies by focus on non-banking financial intermediaries. Financial stability still remained challenging despite prevailing low interest rates aimed at stimulating economic activity by encouraging risk taking. Excesses in some nonbanking financial institutions, and highly leveraged corporate and real estate sectors required MaP monitoring and actions. The banking sector has become more resilient. But slow progress in improving profitability and renewed cyclical headwinds may hamper their ability to respond to future risks. More active use of $\mathrm{MaP}$ instruments, like countercyclical capital buffers, would mitigate stability risks in some countries.

$\begin{array}{ccr}\text { Besides } & \text { ESRB } & \text { guidelines, efficient } \\ \text { communication } & \text { system and improved } & \text { statistical }\end{array}$ 
database European national banking systems, like Romania and Germany, adopted various other approaches to solve the crisis [11]. Germany has applied lessons from the WFC to financial regulation promoting lasting stability [22]. Financial Stability Status Review 2019 [23] still revealed German financial system vulnerability from underestimation of future credit risks and overestimation of recoverability of loan collateral.

Chinese Experience: The People's Bank of China (PBC), the Chinese Central Bank, deals with both monetary and MaP policies with policy objectives of price stability, economic growth, and financial stability [24]. It relies on a toolkit of monetary and credit policy instruments, as well as MaP tools. Findings from the Chinese experience include:

1. Monetary policy tools, like reserve requirements, window guidance $\&$ housing market policies, and supervisory measures used counter-cyclically improve financial stability.

2. A well-designed use of monetary and MaP policies achieves both macroeconomic and financial stability, while each one is effective in restraining excessive credit expansion.

3. MaPP is faster and preferred to monetary policy to contain vulnerabilities.

4. Among different policy instruments, window guidance is particularly effective in curbing credit, while housing market policies are effective in reining in the housing prices.

The design of $\mathrm{MaP}$ measures and assessment of their efficacy are country-specific, and not universal. A multiple-instrument and multiple-objective operating framework enables a central bank to choose different instruments, while addressing different problems. While designing MaPP, central banks or other regulators should monitor and balance the tradeoff between cost and benefit.

Gulf Cooperation Council (GCC) Experience: The recession following the WFC had both direct and indirect negative effects on the economies of GCC countries, though it differed from country to country [25]. The overall GCC picture was:

- Deterioration of Gulf stock markets

- Worldwide fall in prices of \& demand for oil, petrochemicals and aluminum

- Investment project executions delayed or postponed

- Increased unemployment rates, especially of foreign workers

- Value of GCC assets pegged to USD fell from the fall in USD value

The big reserves of foreign currencies with GCC countries accumulated over the past few years enabled them to withstand WFC and implement expansionary policies through pumping liquidity to absorb the recession effects. Though severity of the crisis was alleviated, the result was an increase in inflation and reduction in interest levels, leading to fall in real interest rates and consequent decrease in incentive to saving. Most of the balances used in speculations with GCC currencies were withdrawn with improved dollar status. Non-transparency on the size of losses suffered by governments made it difficult to assess and quantify the same.

Indian Experience: Despite the least exposure to toxic securitized US products, India was not fully insulated [2]. Its economic growth decelerated in 20082009 to $6.7 \%$ from $8.8 \%$ over the last 5 years. The earlier financial reforms by the Reserve Bank of India (RBI, India's Central Bank), like minimizing use of securities and derivatives and insisting on adequate capital requirement to invest in riskier ventures, prevented excess liquidity, retained loan repayment incentive, ensured responsible allocation of savers' money and made banking system less vulnerable. The Union Government also provided fiscal stimulus packages, like tax relief, increased expenditure on public projects and public assets, besides RBI's monetary easing and liquidity enhancing measures. India recovered early to become the fastest growing major economy after China. Boosting India's growth further would require: 1) vigorous pursuit of economic reforms, 2) raising domestic savings by reducing subsidies and non-developmental expenditures, stronger tax enforcement, and incentivizing savings, 3) larger investments in infrastructural services, and 4) greater investment in agriculture, social service sectors and rural development. Destabilizing spillovers from ultralow to negative interest rates in Europe and USA in the form of sudden capital outflows made RBI struggle to keep financial system stable [20]. Despite India's expertise in handling the effects on local credit and asset markets, a prolonged exposure might cause profound collateral damage.

Brazilian Experience: Brazil is a South American emerging market economy. Though severely hit by WFC, the impact did not last long [26]. Restructuring Brazilian banking system with prudential regulation after the Real Plan in mid 1990's increased their resilience and shortened the crisis duration. Increased mergers and acquisitions by both domestic and foreign institutions saved insolvent banks without great expenditure of federal funds. Entry of foreign bank helped in increasing efficiency and introduction of new technology without reducing net interest margins of the banking sector. Lessons from their crisis management include:

- Though a strong prudential regulation is important, too much of it could affect the financial system efficiency.

- A better monitoring framework of banking and non-banking financial institutions would increase transparency, lead to standardization of derivatives 
contracts and limit their liquidation to futures exchanges.

- Entry of foreign banks and foreign competition makes banking more solid.

- "A high degree of openness being not necessarily good" policy enabled the Brazilian banking system avoid financial operations of high risk and high returns.

- Though too-big-to-fail philosophy leads to a moral hazard, the alternative of not letting the bigger banks fail is also necessary to avoid systemic crisis.

- Relaxation of prudential regulation does not increase credit supply, but makes banks more prone to engage in riskier operations.

Australian Experience: Australia did not experience a large economic downturn [1]. But the pace of economic growth slowed significantly, the unemployment rose sharply with prevalent uncertainty. The causes of a relatively strong performance:

- Meager exposures of Australian banks to the US housing market and banks

- Strict lending standards of Australian Prudential Regulation Authority (APRA) limiting the share of high risk loans

- Trade links to robust Chinese economy

Despite strong regulations and lending standards, a strong policy response was needed to avoid a major downturn. The Reserve Bank of Australia lowered the interest rate significantly, and the Government undertook expansionary fiscal policy and provided guarantees on deposits and bonds issued by Australian banks.

Australia escaped recession with little suffering from population growth through immigration and having China as trading partner. The lead role between the two is debated [27]. Aussie banks were able to raise short-term capital after the crisis due to their strong credit ratings. The government also helped by a three-year uncapped bank deposit guarantee in November 2008, a source of low-cost funds for the banks. Despite decline in per capita income, the economy still expanded. Australia skipped housing collapse, as demand for housing outstripped supply for the same reasons and house prices were maintained. Though many suffered from loss of jobs, Australians got off extremely lightly by global standards. GDP and housing markets held up remarkably well with assistance from the Government stimulus programs, like the home buyer's grant and the Nation Building program, which saved 150,000 to 200,000 jobs. Australian business leaders were optimistic that Australia's rebound looked sustainable. But, things appear uncertain as to how the economy is going to survive with a quick safe exit, when the stimulus is withdrawn and debts incurred are recovered.
The present conceptual study analyzes various economic policy options for governments, central banks, and other regulatory/supervisory bodies, indicators of systemic vulnerabilities, choice of tools and instruments for instability in different settings, and the way forward in judicious use of different economic policies and strategies. An extensive search of literature was undertaken to arrive at conclusions of value in containment or prevention of future economic shocks and for adopting granular approaches, which are country, industry, issue or market-specific, to achieve and maintain financial stability. The experiences of some advanced and emerging economies of the world were considered for guidance.

\section{CONCLUSION}

\section{Relevant conclusions after study of a wealth of worldwide experiences:}

- Macroprudential policy measures are the first line defense against financial instability. It may sometimes work alone, but always better in coordination with other economic policies and international coordination.

- Macroprudential policy would be very effective, if implemented counter-cyclically and with balance between financial stability and efficiency.

- Macro and micro prudential measures have many complementarities, and a few conflicts. The former can be enhanced and the latter can be averted by suitable measures. A judicious use of both ensures financial stability.

- Exclusive reliance on macroprudential measures is not cost-effective. The rigorousness in their implementation can be minimized and a tradeoff between macroeconomic and financial stability avoided by exploiting pro-stability aspects of other economic policies.

- Prudential measures are not a fit-for-all. A granular approach with judicious, flexible use of prudential instruments and tools with attention to details, like country, industry, market, sector, issue or situation, is needed.

- Whatever the model in responsibility allocation for financial stability, the basic minimum are clear mandates, accountability and transparency with a major role and safeguards for independence of central bank.

- The wealth of information on indicators, tools, instruments and tests in prudential and other economic policies need careful study, analysis and consideration for use as per needs of the situation for optimal results.

- There is need for an efficient, effective framework for supervision, regulation and surveillance by information gathering on macroeconomy and financial system to assess risks and suggest suitable actions.

- Monetary or price stability, in the absence of financial stability, would not guarantee

\section{RESEARCH METHODOLOGY}


macroeconomic stability. Financial stability paves the way for a sustainable economic growth, macroeconomic stability and welfare.

- Better be proactive than reactive in confronting vulnerabilities and risks!

- Financial stability is best insured by creating financial infrastructure and framework, as "the best way to predict future is to create it"!

\section{REFERENCES}

1. Reserve Bank of Australia Explainer. (N.D.). The Global financial Crisis. Retrieved from the RBA website:

https://www.rba.gov.au/education/resources/ explainers/the-global-financial-crisis.html

2. Peddada, K. (2014, December 12). Root causes and remedies for global financial crises: Lessons from a success story [Unpublished presentation]. Conference on Contemporary Global Economic Issues. University of Allahabad, India

3. Magyar Nemzeti Bank. (2019). Defining Financial Stability [Reports]. Retrieved from MNB website: https://www.mnb.hu/en/ financialstability/defining-financial -stability

4. Bank of Korea Publication. (2019). Definition and importance of financial stability. Retrieved from Bank of Korea website: https://www.bok.or. kr/eng/ main/contents. do?menuNo=400037

5. World Bank. (2019). Financial Stability [Publication]. Retrieved from WB website: https://www.worldbank.org/en/publication/gfdr/gf dr-2016/background/

6. Bank of England. (2019). What is financial stability? [KnowledgeBank]. Retrieved from Bank of England website: https://www.bankofengland.co.uk/ knowledgebank /what-is-financial-stability

7. European Central Bank. (2005, June). Assessing financial stability: Conceptual boundaries and challenges, Financial Stability Review, pp.117125. Retrieved from ECB website: https://www. ecb. europa.eu/pub/pdf/fsr/art/ecb.fsrart200506 _01.en.pdf

8. Cockeran H. J. (2016). South Africa's Macroeconomic Resilience to External Shocks: A Comparison to its BRICS Partners. International Journal of Economics \& Finance Studies. $8(1): 145-160$

9. Vučinić, M. (2016, September 23). Importance of macroprudential policy implementation for safeguarding financial stability. Journal of Central Banking Theory and Practice, 5(3), pp. 79-98. Retrieved from: https://doi.org /10.1515/jcbtp2016-0021

10. International Monetary Fund. (2000, April). Macroprudential indicators of financial system soundness [Occasional Paper 192]. Washington, D.C.: IMF. Retrieved from: https://www.imf.org/external/pubs/ft/op/ 192/OP192.pdf
11. ESRB. (2013, April 4). Intermediate objectives and instruments of macro-prudential policy [Recommendations]. European Systemic Risk Board. Retrieved from: https://www. esrb.europa.eu/pub/pdf/ recommendations/2013/ESRB_2013_ 1.en.pdf

12. Donath L, Veronica, M. C., \& Oprea, I. (2015). The monetary macroprudential policy stance in safeguarding financial stability: The case of Romania: Retrieved from: https://doi.org/10.1016/S2212-5671(15)01371-4

13. Capital.com. (N.D.). Microprudential regulation. Retrieved from: https://capital. com/microprudential-regulation-definition

14. Blahova, N. (2015). The relation between macroprudential and microprudential policy: An example of regulatory bank capital. Procedia Economics and Finance, 25, 428-434. Elsevier. Retrieved from: http://doi.org/10.1016/S22125671(15)00754-6

15. Borio, C. (2003, February). Towards a macroprudential framework for financial supervision and regulation? CESifo Economic Studies, 49(2), 181-215

16. Chappelow, J. (2019, November 8). Economic cycle. Investopedia. Retrieved from: https://www. investopedia.com/terms/e/economic-cycle.asp

17. Ekpu, V. (2016, October). Microprudential vs macroprudential approaches to financial regulation and supervision [Presentation]. Presented at Regional Course on Advanced Banking Supervision and Financial Stability. Lagos, Nigeria: West African Institute for Financial and Economic Management. Retrieved from: https://www.researchgate. net/publication/311935564_Micro-prudential_Vs_ Macro-prudential_Approaches_to_ Financial_Regulation_and_Supervision

18. Osiński, J., Seal, K., \& Hoogduin, L. (2013, June). Macroprudential and microprudential policies: Toward cohabitation [Staff discussion note13/05]. International Monetary Fund. Retrieved from IMF website: https://pdfs. semanticscholar.org/ e194/237fde5d 6f23bb94530ef43406604d5891c7.pdf

19. Rich, R. (2013, November 22). The Great Recession. Federal Reserve History. Retrieved from Federal Reserve's website: https://www.federalreservehistory. org/essays/great_recession_of_200709

20. Peddada, K. (2017). Impact of unconventional monetary policies of advanced economies on emerging Asian economies. Indian Journal of Finance. 11 (12).pp 7-19. Retrieved from: http://dx.doi. org/10.17010/ijf/2017/v11i12/119939

21. European Central Bank. (2019, November 20). Financial Stability Review [Publication]. Retrieved from ECB website: 
https://www.ecb.europa.eu/pub/ financial-stability/ fsr/html/ecb.fsr201911 facad0251f.en. html

22. Deutsche Bundesbank. (2013, April). Macroprudential oversight in Germany: Framework, institutions and tools [Monthly report, pp. 39-44]. Retrieved from D.B. website: https://www.bundesbank.de/resource/ blob/625770/ b50a887b 617354968fc661b 6ee18e 293/mL/2013-04-macroprudential-oversightdata.pdf

23. Deutsche Bundesbank. (2019, November 21). Financial stability review- 2019 [Publication]. Retrieved from D.B. website: https://www.bundesbank.de/en/press/ pressreleases/the-deutsche-bundesbank-publishes-its2019-financial-stability-review-814958

24. Klingelhofer, J., \& Sun, R. (2019). Macroprudential policy, central banks and financial stability: Evidence from China. Journal of International Money and Finance, 93(5):19-41. Retrieved from: https://doi.org/ 10.1016/j.jim

25. Abdelbaki, H. H. (2010). Assessing the impact of the global financial crisis on GCC countries. Journal of Business \& Economics Research, 8(2):139-152. Retrieved from: https://doi.org/10.19030/ jber.v8i2.682

26. Sobreira, R., \& de Paula, L. (2010). The 2008 financial crisis and banking behavior in Brazil: The role of the prudential regulation. Journal of Innovation Economics \& Management, 6(2), 7793. https://doi.org/ 10.3917/jie.006.0077

27. Dobbie, P. (2009, October 26). How Australia ducked the crisis? [Moneywatch]. CBS News. Retrieved from: https://www.cbsnews.com/news/how-australiaducked-the-crisis/ 